\title{
Set-Based Concurrent Engineering process within the LeanPPD environment
}

\author{
Muhammad Khan ${ }^{\mathrm{a}}$, Ahmed Al-Ashaab ${ }^{\mathrm{a}, 1}$, Athanasia Doultsinou ${ }^{\mathrm{a}}$, Essam Shehab ${ }^{\mathrm{a}}$, \\ Paul Ewers ${ }^{\mathrm{b}}$, Robert Sulowski ${ }^{\mathrm{c}}$ \\ ${ }^{a}$ Manufacturing Department, School of Applied Sciences, Cranfield University, \\ MK43 0AL, United Kingdom \\ ${ }^{\mathrm{b}}$ Visteon Engineering Services Ltd, United Kingdom \\ ${ }^{\mathrm{c}}$ Sitech Sp. z o.o, Poland
}

\begin{abstract}
This paper presents a newly defined set-based concurrent engineering process, which the authors believe addresses some of the key challenges faced by engineering enterprises in the $21^{\text {st }}$ century. The main principles of Set-Based Concurrent Engineering (SBCE) have been identified via an extensive literature review. Based on these principles the SBCE baseline model was developed. The baseline model defines the stages and activities which represent the product development process to be employed in the LeanPPD (lean product and process development) project. The LeanPPD project is addressing the needs of European manufacturing companies for a new model that extends beyond lean manufacturing, and incorporates lean thinking in the product design development process.
\end{abstract}

Keywords. Set-based concurrent engineering, lean thinking, LeanPPD, product development

\section{Introduction}

Lean thinking is an improvement philosophy which focuses on the creation of customer-defined value and the elimination of waste. Lean thinking has been a subject of research for nearly three decades, the focus of which has been on improving manufacturing processes, administration, management and the supply chain. However, new engineering products continue to under-perform in their lead times, cost, and quality. There has been comparatively less research done to improve product design and development (PDD): the design process, from the concept stage, to the detailed development of products and their related manufacturing processes. The reasons for this are many; however PDD has the greatest influence on the profitability of any product [3]. Research undertaken to improve PDD with lean thinking may prove instrumental in the progress of engineering.

\footnotetext{
${ }^{1}$ Manufacturing Department, School of Applied Sciences, Cranfield University, MK43 OAL, United Kingdom, Tel: +441234750111, ext.5622, E-mail: a.al-ashaab@cranfield.ac.uk
} 
Most product development models have been developed in order to meet the challenges and situation at the time that they were created. However, the market and environment for engineering products is almost as turbulent as white water rapids. In order to develop a product development model that is fit to consistently perform in a rapidly changing market and environment, a changeless core is required. While comparing various engineering companies a number of US researchers realised that the Toyota motor co. had established a changeless core that was based on principles, focus and discipline [7]. Toyota product development focuses on three central elements: value, knowledge (or learning) and improvement. The authors believe that this focus has enabled them to please customers through optimal designs, minimise design rework, and achieve high profit levels. In order to reach the aforementioned achievements, they developed a process that is now known as set-based concurrent engineering (SBCE); however there is no publication that describes the methodology of this process in detail that would help organisations to introduce and implement it into their product development process.

This paper presents a newly defined SBCE process for the LeanPPD project and is structured into five sections, namely a review of SBCE, SBCE principles, SBCE baseline model, SBCE process and finally conclusions and future work.

\section{A Review of Set-Based Concurrent Engineering}

[7] advocate that set-based concurrent engineering (SBCE) is potentially the underlying cause for Toyota's various successes. They looked for evidence of a scientific product development approach in the Japanese and US automotive industries, and found it being practiced at the Toyota Motor Co. This work provided a case study of Toyota PD, but does not present a detailed process or methodology for SBCE. [5] built on this case study and provided more explanation for the SBCE process. The authors describe SBCE through an organised group of principles and a number of additional mechanisms that have been briefly described. The authors described the process as follows:"Design participants practice SBCE by reasoning, developing, and communicating about sets of solutions in parallel. As the design progresses, they gradually narrow their respective sets of solutions based on the knowledge gained. As they narrow, they commit to staying within the sets so that others can rely on their communication."

The above definition means that traditional product development approaches including point-based CE select one conceptual design as early as possible in the development process. This causes costly re-work as well as some of the resources are not going to be available at the re-work stage. In SBCE, the selection of the design is delayed as the design set is gradually narrowed based on the knowledge available to support decision taking. This will reduce or eliminate the re-work. [6] also compiled a textbook that described a number of Toyota PD mechanisms in detail with convincing arguments and simple rationale. The author states that the secret to lean product development is "learning fast how to make good products" and maintains this focus on learning, creating 'usable' knowledge and producing consistently profitable operational value streams throughout. Operational value 
streams are described as "the output of development and run from suppliers through plants into product features and out to customers" [6]. Ward emphasises on SBCE, supported by trade-off curves as the key elements of lean product development. Trade-off curves are graphs that evaluate one design attribute against another for a number of alternatives. In this approach the team breaks the system down into sub-systems and sub-sub-systems, identify broad targets at each level, and create multiple concepts for each component and whole system. They then filter concepts by aggressive evaluation, while capturing information in the form of trade-off curves and finally filter and converge based on the knowledge acquired.

Some of the typical challenges faced in product development are addressed by SBCE. These are explained in Table 1.

Table 1: SBCE and Challenges faced in product development

\begin{tabular}{|l|l|}
\hline Challenge & How SBCE Addresses the Challenge \\
\hline Rework & $\begin{array}{l}\text { Problematic design options are ruled out by developing and } \\
\text { evaluating multiple alternatives in parallel }\end{array}$ \\
\hline Sub-optimal Designs & $\begin{array}{l}\text { Customer value is internalised and communicated holistically } \\
\text { to all designers }\end{array}$ \\
\hline Knowledge Crisis & $\begin{array}{l}\text { An effective and coherent knowledge life-cycle facilitates the } \\
\text { capture, representation and provision of the right knowledge } \\
\text { to the right people at the right time }\end{array}$ \\
\hline Lack of Innovation & $\begin{array}{l}\text { Specific time and resources are scheduled for innovation, } \\
\text { and multiple options must be considered as part of the } \\
\text { process }\end{array}$ \\
\hline High Unit Cost & $\begin{array}{l}\text { By reducing rework, focusing on customer value, and } \\
\text { improving communication and the process of PD, unit cost is } \\
\text { reduced }\end{array}$ \\
\hline
\end{tabular}

\section{Set-Based Concurrent Engineering Principles}

This section presents the main principles of Set-Based Concurrent Engineering as identified in several literature sources. The principles have been classified in five categories (Table 2), namely strategic value research and alignment, map the design space, create and explore multiple concepts in parallel, integrate by intersection and establish feasibility before commitment.

Table 2: SBCE categories and principles

\begin{tabular}{|l|l|}
\hline Category & Principle \\
\hline $\begin{array}{l}\text { 1. Strategic value } \\
\text { research and } \\
\text { alignment }\end{array}$ & $\begin{array}{l}\text { - Classify projects into a project portfolio [4,6] } \\
\text { - Explore customer value for project X } \\
\text { - Align each project with the company value strategy } \\
\text { - Translate customer value (product vision) to designers (via } \\
\text { concept paper) [4,5] }\end{array}$ \\
\hline $\begin{array}{l}\text { 2. Map the } \\
\text { design Space }\end{array}$ & $\begin{array}{l}\text { - Break the system down into subsystems [6] } \\
\text { - Identify essential characteristics for the system [6] } \\
\text { - Decide on what subsystems/components improvements should }\end{array}$ \\
\hline
\end{tabular}




\begin{tabular}{|c|c|}
\hline & $\begin{array}{l}\text { be made and to what level (selective innovation) [6] } \\
\text { - Define feasible regions based on knowledge, past experience } \\
\text { and the Chief engineer, and consider the different } \\
\text { perspectives/functional groups [5] }\end{array}$ \\
\hline $\begin{array}{l}\text { 3. Create and } \\
\text { explore } \\
\text { multiple } \\
\text { concepts in } \\
\text { parallel }\end{array}$ & $\begin{array}{l}\text { - Pull innovative concepts from R\&D departments [6] } \\
\text { - Explore trade-offs by designing multiple alternatives for } \\
\text { subsystems/components [5] } \\
\text { - Schedule time for innovation and problem solving while the set } \\
\text { of alternatives is broad }[4,6] \\
\text { - Ensure many possible subsystem combinations to reduce the risk } \\
\text { of failure [6] } \\
\text { - Extensive prototyping (physical and parametrical) of alternatives } \\
\text { to test for cost, quality, and performance }[4,5,6,7] \\
\text { - Perform aggressive evaluation of design alternatives to increase } \\
\text { knowledge and rule out weak alternatives [5,6] } \\
\text { - Information goes into a trade-off knowledge base that guides the } \\
\text { design [6] }\end{array}$ \\
\hline $\begin{array}{l}\text { 4. Integrate by } \\
\text { intersection }\end{array}$ & $\begin{array}{l}\text { - Look for intersections of feasible sets, including compatibility } \\
\text { and interdependencies between components }[4,5,6] \\
\text { - Impose minimum constraints: deliberate use of ranges in } \\
\text { specification and initial dimensions should be nominal without } \\
\text { tolerances unless necessary [5] } \\
\text { - Seek conceptual robustness against physical, market, and design } \\
\text { variations [5,6] } \\
\text { - Concurrent consideration of lean product design and lean } \\
\text { manufacturing }\end{array}$ \\
\hline $\begin{array}{l}\text { 5. Establish } \\
\text { feasibility } \\
\text { before } \\
\text { commitment }\end{array}$ & $\begin{array}{l}\text { - Narrow sets gradually while increasing detail: functions narrow } \\
\text { their respective sets based on knowledge gained from analysis } \\
\text { - Delay decisions so that they are not made too early or with } \\
\text { insufficient knowledge }[5,6] \\
\text { - Design decisions should be valid for the different sets and } \\
\text { should not be effected by other subsystems [5] } \\
\text { - Stay within sets once committed and avoid changes that expand } \\
\text { the set [5] } \\
\text { - Control by managing uncertainty at process gates [5] } \\
\text { - Manufacturing evaluates the final sets and dictates part } \\
\text { tolerances [5] } \\
\text { - Manufacturing begins process planning before a final concepts } \\
\text { has been chosen and thus act on incomplete information [5] } \\
\text { - Delay releasing the final hard specification to major suppliers } \\
\text { until late in the design process [6] }\end{array}$ \\
\hline
\end{tabular}

\section{Set-Based Concurrent Engineering Baseline Model}

After a critical analysis of the SBCE principles The captured SBCE principles have been analysed against the traditional product development approaches [2] and the various descriptions of the SBCE process, a number of phases were defined in order to represent the SBCE process. Although the phases may appear similar to some traditional PD models, the activities within them are unique and thus the 
phase names are intentionally unusual. Figure 1 illustrates graphically the SBCE baseline model that has been developed based on the captured principles. Customers and suppliers are involved throughout the product development process. During the first phase: value research, the initial product concept definition is developed based on a strategic and thorough internalisation and analysis of value. In phase 2: map the design space, design participants or subsystem teams define the scope of the design work required as well as the feasible design options/regions. In the third phase: concept set development, each participant or subsystem team develops and tests a set of possible conceptual sub-system design solutions; based on the knowledge produced in this phase some weak alternatives will be eliminated. In phase 4: concept convergence, sub-system intersections are explored and integrated systems are tested; based on the knowledge produced in this phase the weaker system alternatives will be purged allowing a final optimum product design solution to enter phase 5: detailed design.

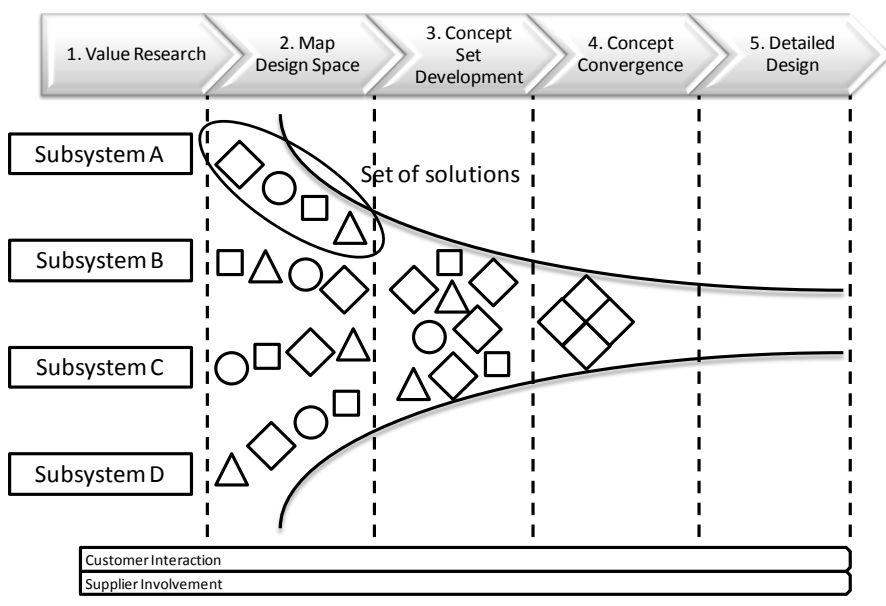

Figure 1: SBCE baseline model

\section{Set-Based Concurrent Engineering Process}

The SBCE process consists of several key phases, as shown in Figure 2.

Each phase is divided into activities, which are described as follows:

1. Value Research:

1.1 Classify project type: the project will be classified and defined according to the level of innovation that will be incorporated (e.g. minor/ major modifications)

1.2 Identify customer value: Customer value should be thoroughly understood in order to determine system targets and will be used throughout product development to measure the leanness of the alternative product designs 
1.3 Align with company strategy: The project will be aligned with the company strategy to assess how the company can take strategic advantages from the project, such as increased process value

1.4 Translate customer value to product designers via product concept definition

\begin{tabular}{|c|c|c|c|c|}
\hline 1. Value Research & $\sum_{\text {Design Space }}^{2 . \text { Map }}$ & $\begin{array}{c}\text { 3. Concept } \\
\text { Set } \\
\text { Development }\end{array}$ & $\begin{array}{c}4 . \text { Concept } \\
\text { Convergence }\end{array}$ & $\begin{array}{l}\text { 5. Detailed } \\
\text { Design }\end{array}$ \\
\hline $\begin{array}{l}1.1 \text { Classify project } \\
\text { type }\end{array}$ & $\begin{array}{l}2.1 \text { Identify sub- } \\
\text { system targets }\end{array}$ & $\begin{array}{l}3.1 \text { Pull design } \\
\text { concepts }\end{array}$ & $\begin{array}{l}4.1 \text { Determine set } \\
\text { intersections }\end{array}$ & $\begin{array}{l}5.1 \text { Release final } \\
\text { specification }\end{array}$ \\
\hline $\begin{array}{l}1.2 \text { Explore customer } \\
\text { value }\end{array}$ & $\begin{array}{l}2.2 \text { Decide on level of } \\
\text { innovation to sub- } \\
\text { systems }\end{array}$ & $\begin{array}{l}3.2 \text { Create sets for } \\
\text { each sub-system }\end{array}$ & $\begin{array}{l}4.2 \text { Explore system } \\
\text { sets }\end{array}$ & $\begin{array}{l}5.2 \text { Manufacturing } \\
\text { provides tolerances }\end{array}$ \\
\hline $\begin{array}{l}1.3 \text { Align with } \\
\text { company strategy }\end{array}$ & $\begin{array}{l}2.3 \text { Define feasible } \\
\text { regions of design } \\
\text { space }\end{array}$ & $\begin{array}{l}3.3 \text { Explore sub- } \\
\text { system sets: } \\
\text { prototype \& test }\end{array}$ & $\begin{array}{l}4.3 \text { Seek conceptual } \\
\text { robustness }\end{array}$ & $\begin{array}{l}5.3 \text { Full system } \\
\text { definition }\end{array}$ \\
\hline \multirow[t]{3}{*}{$\begin{array}{l}\text { 1.4 Translate } \\
\text { customer value to } \\
\text { designers }\end{array}$} & & $\begin{array}{l}3.4 \text { Capture } \\
\text { knowledge and } \\
\text { evaluate }\end{array}$ & $\begin{array}{l}4.4 \text { Evaluate sets for } \\
\text { lean production }\end{array}$ & \\
\hline & & $\begin{array}{l}3.5 \text { Communicate } \\
\text { set to others }\end{array}$ & $\begin{array}{l}4.5 \text { Being process } \\
\text { planning for } \\
\text { manufacturing }\end{array}$ & \\
\hline & & & $\begin{array}{l}4.6 \text { Converge on } \\
\text { final set of sub- } \\
\text { system concepts }\end{array}$ & \\
\hline
\end{tabular}

Figure 2: SBCE process and activities

2. Map Design Space:

2.1 Decide on the level of innovation for system/ subsystems/ components (as appropriate): Each team will decide on which system/ subsystems/ components improvements should be made and to what level

2.2 Identify system/ subsystem/ component targets: Each team will analyse their architecture and identify their own lower-level targets (essential characteristics) based on the system targets and product concept template

2.3 Define feasible regions of design space: These are defined based on knowledge and past experience while considering the views/ constraints of different functional groups

3. Concept Set Development:

3.1 Extract design concepts: Innovative concepts can be extracted from previous projects, $R \& D$ departments and competitor products

3.2 Create tests for each subsystem: Design teams brainstorm so that a set of design solutions is created

3.3 Explore subsystem sets: simulate/ prototype and test; Alternative solutions must be simulated/ prototyped and tested for cost, quality and performance

3.4 Dynamic knowledge capture and evaluation: Knowledge that has been created must be captured (in a quantitative and qualitative manner) in order to evaluate the sets 
3.5 Communicate sets to others: Each team will present their set to others in order to receive feedback and understand constraints

4. Concept Convergence:

4.1 Determine set intersections: Potential systems will be integrated by the intersection of feasible sets, including compatibility and interdependencies between components

4.2 Explore system sets: Potential systems should be simulated/ prototyped (parametric and physical) and tested for cost, quality and performance

4.3 Seek conceptual robustness: Conceptual robustness will be sought against physical, market and design variations in order to reduce risk and improve quality

4.4 Evaluate sets for lean production: Once the potential systems have been explored, they will be evaluated for lean production to assess the costs, efficiency, problems, etc.

4.5 Begin process planning for manufacturing: Based on the evaluations, manufacturing can begin process planning for the possible sets that have been agreed to be feasible

4.6 Converge on the final set of subsystem concepts: Based on the evaluations and knowledge captured, sub-optimal system designs have to be eliminated and the proven optimal design from the system set is finalised

5. Detailed Design:

5.1 Release final specification: The final specifications will be released once the final set is concluded

5.2 Tolerances' provision: Manufacturing will provide part tolerances to the design teams

5.3 Full system definition: Further detailed design work will follow.

\section{Conclusions and Future Work}

The research presented in this paper provides an overview of the Set-Based Concurrent Engineering (SBCE) process that is being developed as part of the LeanPPD project [1]. This research extends the work of [5] and others who identified the merits of SBCE by providing a detailed and structured SBCE process. In order to develop a product development model that is fit to consistently perform in a rapidly changing market and environment a changeless core is required. The authors are developing a product development model that has a changeless core based on principles, which focuses on three central elements: value, knowledge (or learning) and improvement. The authors believe that this focus will enable companies to please customers through optimal designs, minimise design rework, and achieve high profit levels. The presented set-based concurrent engineering (SBCE) process addresses challenges that are faced by engineering companies in the $21^{\text {st }}$ century and provides significant benefits over traditional approaches with regards to challenges such as rework, knowledge provision, and lack of innovation.

The research presented in this paper is work in progress. The activities defined in the SBCE baseline model and currently being developed so that they embody state-of-the-art product development methods while maintaining a focus on the 
principles upon which the process is based. Longitudinal studies are in progress within automotive, aerospace and home appliance sectors to understand the specific organisations needs to which the process will be applied and tested.

\section{Acknowledgements}

The research presented in this paper has been conducted as part of a European project titled 'Lean Product and Process Development (LeanPPD)'. The project involves multiple research and industrial partners from the UK, Spain, Germany, Italy and Poland. The project is supported by the Commission of European Community, contract number NMP-2008-214090) under the NMP Programme (Nanosciences, Nanotechnologies, Materials and new Production Technologies). The authors wish to acknowledge the European Commission for its support as well as the other partners in the consortium (http://www.leanppd.eu).

\section{References}

[1] Al-Ashaab, A., Shehab, E., Alam, R., Sopelana, A., Sorli, M., Flores, M., Taisch, M., Dragan Stokic, D. and James-Moore, M., (2010). The Conceptual LeanPPD Model. The 17th ISPE International Conference on Concurrent Engineering September, Cracow, Poland

[2] Atkinson, D and Al-Ashaab, A. (2008) A review and critical analysis of global New Product Introduction and Development, Int J of Product Development, vol. 6, no.2, pp. 118141.

[3] Duverlie, P. and Castelain, J. (1999), "Cost estimation during design step: parametric method versus case based reasoning method", The international journal of advanced manufacturing technology, vol. 15, no. 12, pp. 895-906.

[4] Morgan, J.M. and Liker, J.K. (2006) The Toyota Product Development System, New York: Productivity Press.

[5] Sobek, D. K., Ward, A. C. and Liker, J. K. (1999), "Toyota's principles of set-based concurrent engineering", Sloan management review, vol. 40, no. 2, pp. 67-84.

[6] Ward, A.C. (2007) Lean Product and Process Development, Cambridge, MA, USA: Lean Enterprise Institute.

[7] Ward, A.C., Liker, J. K., Cristiano, J. J. and Sobek, D. K. (1995), "The second Toyota paradox: How delaying decisions can make better cars faster", Sloan management review, vol. 36 , pp. 43-43. 